\title{
A Cooperative Study of Self-Esteem, Leadership and Resilience amongst Illegal Motorbike Racers and Normal Adolescents in Malaysia
}

\author{
Wan Shahrazad, W. S. ${ }^{1}$, Fauziah I. ${ }^{1}$, Asmah Bee M. N. ${ }^{1}$ \& Ismail B. ${ }^{2}$ \\ ${ }^{1}$ School of Psychology and Human Development, Faculty of Social Sciences and Humanities, Universiti \\ Kebangsaan Malaysia, Bangi, Malaysia \\ ${ }^{2}$ School of Applied Physics, Faculty of Science and Technology, Universiti Kebangsaan Malaysia, Bangi, \\ Malaysia
}

Correspondence: Wan Shahrazad, W. S., School of Psychology and Human Development, Faculty of Social Sciences and Humanities, Universiti Kebangsaan Malaysia, 43600 UKM Bangi, Selangor, Malaysia. Tel: 60-3-8921-5211. E-mail: shara@ukm.my

Received: February 2, 2012

Accepted: April 13, $2012 \quad$ Published: July 1, 2012

doi:10.5539/ass.v8n8p61

URL: http://dx.doi.org/10.5539/ass.v8n8p61

\begin{abstract}
Understanding self-esteem, leadership and resilience among at risk youth who are involved in illegal motorbike racing is a crucial issue prior to starting any intervention programs. It may provide an indication of their profile in order to change this negative behavior. This study aimed in examining the relationship between self-esteem, leadership and resilience among illegal motorbike racers and its comparison with normal adolescents. The study employed survey research involving the administration of three standardized psychological tests namely the Rosenberg Self-Esteem Scale (RSE), the adapted Multifactor Leadership Questionnaire (MLQ) and the Resilience Questionnaire (RQ). A total of 140 respondents participated in this study. Data were analyzed using Pearson correlation and t-test analysis. Results showed that there were significant correlations between self-esteem, leadership and resilience dimensions among normal adolescents. However there were no significant correlations between self-esteem, leadership and resilience dimensions among illegal motorbike racers. In addition, there were significant differences of self-esteem, leadership and resilience between normal adolescents and illegal motorbike racers. In conclusion, normal adolescents had higher self-esteem and leadership and they showed higher resilience while illegal motorbike racers showed lower self-esteem and leadership and in turn they were less resilient. This implied the need for continuous intervention programs in order to empower at risk youth. It was recommended that future studies explore other variables such as family and school variables that can influence resilience.
\end{abstract}

Keywords: self-esteem, leadership, resilience, at risk youth, illegal motorbike racers

\section{Introduction}

The well-being of any country depends on successful young generation to step forward and replace the older generation in governing a country. As such, preparing well-adjusted adolescents become an important agenda in nurturing potential leaders. This means, we need normal adolescents who are physically, mentally, psychologically and spiritually healthy. Yet, this is a daunting task because adolescents are those individuals most at risk in this period where they experience identity crisis and this can become a "storm and stress" time. Many adolescents successfully undergo this period to become successful individuals who then have stable careers and families and contribute significantly to the society. On the other hand, there are those who do not succeed and succumb to the negative influences of social problems such as delinquency, drug addiction and crime.

In Malaysia, the social problems that involve groups of illegal motorbike racers or known as "mat rempit" has become a national issue (Zaid, Nobaya \& Haslinda, 2009). These individuals who are categorized as at risk youth become the focus of media as they usually race on the road in groups and endanger the public and other road users. Recently, these illegal motorbike racers have been linked to gangsterism, street fighting, assault, 
vandalism, theft and bullying. The group often comprises young and aggressive males and females riding motorbikes and racing with each other in the middle of traffic. They normally not only engage in racing among themselves but also challenge other road users to race with them (Zaid et al., 2009). A study conducted by Jackson and Wilson (1993) found that motorcycle gang members in Great Britain were tough, aggressive, sensation seeking, risk taking, irresponsible and lacking in self esteem and ambition. As an effort to understand illegal motorbike racers' personality, the concept of self-esteem, leadership and resilience should be examined among them.

According to Malbi and Reasoner (2000), self-esteem can be broadly defined as the overall evaluation of oneself in either a positive or negative way. This is consistent with Rosenberg (1965) who says that self-esteem is a positive or negative orientation towards oneself and evaluation towards self-worth. People with higher self-esteem rate themselves as better at making new friends, at communicating about themselves, at providing emotional support, and at resolving interpersonal conflicts, as compared to people with lower self-esteem (Buhrmester Furman, Wittenberg \& Reis, 1988).

Another variable that needs to be investigated in relation to self-esteem is leadership. This is because the social problem of illegal motorbike racers is a group-based activity and many adolescents become influenced to join a group based on the strength and charisma of its leader. Yet leadership in this context gives a negative connotation. It is noteworthy to explore the characteristics of leadership among these illegal motorbike racers.

Northouse (2009) defines leadership as a process whereby an individual influences a group of individuals to achieve a common goal. This definition is consistent with Yukl (2006) who says that leadership is a process of influencing others to agree on what to do and facilitate the efforts of individuals to achieve a common goal. Without influence, leadership does not exist. Northouse (2009) further defines leadership in term of power relationship that exists between leaders and followers. Hollander (1992) and Jago (1982) state that people who engage in leadership will be called leaders, and those toward whom leadership is directed will be called followers.

A third important variable for individual self-empowerment is resilience. Klarreich (1998) states that resilience include the capacity to face challenges and to somehow become more capable despite adverse experiences. While Masten (2001) emphasizes that resilience is a process, rather than a fixed constitutional attribute, influenced by everyday decisions. According to this interpretation resilience is conceptualized as a protective mechanism that modifies an individual's response to risk situations and operates at critical points during one's life (Newcomb, 1992). Thus, it is an important variable to be studied in relation with illegal motorbike racers who are considered at-risk youth vulnerable to negative influences.

Werner and Smith $(1992,1982)$ say that the study of resilience in its early literature mostly looked at individuals who, against expectations, survived adverse events in their care-giving environment. Resilient individuals are considered to have a hardy personality, because hardy individuals are likely to employ adaptive coping strategies and not maladaptive responses like denial or behavioural avoidance (Kaplan, 1999). In other words, resilience serves as a buffer against the deleterious effects of exposure to violence, maltreatment, abuse or victimization. Individuals having resilience see adversity as temporary and limited in scope and as such they develop positive outlook to life (Salami, 2010).

Personality attributes that appear to be characteristics of resilient children such as high self-esteem, an internal locus of control, and an optimistic outlook of the future are cited extensively in the literature (Barnard, 1994; Benard, 1991, 1995; Clark, 1995; Garmezy, 1991; Garmezy \& Rutter, 1983; Hauser, Vieyra, Jacobson \& Wertlieb, 1985; Hutchinson, Tess, Gleckman \& Spence, 1992; Kurth-Schai, 1988; Linquanti, 1992; Masten, Best \& Garmezy, 1990; McMillan \& Reed, 1994; Murphy, 1987; Rutter, 1979, 1987; Tarwater, 1993; Walker \& Greene, 1987; Werner \& Smith, 1982). Other salient protective factors implicated in resilience research include abstract, reflective and flexible problem-solving abilities (Benard, 1991; Garmezy, 1991; Linquanti, 1992; Masten et al., 1990; Rhoads, 1994) and a display of temperamental characteristics and social skills that elicit positive responses from individuals around them (Benard, 1991; Bushweller, 1995; Clark, 1995; Gore \& Eckenrode, 1994; Hauser et al., 1985; McMillan \& Reed, 1994; Stuart, 1994; Tarwater, 1993). This study examined the ability of early risk factors to predict delinquency referrals. Green, Gesten, Greenwald and Salcedo (2008) studied the significant risk factors which included externalizing behaviors, prenatal smoking, parent marital status, and mother's education. Findings indicated that students with three or more risk factors had eight times the number of delinquency referrals than those with no identified risk factors (Green et al., 2008).

Children who engage in positive self-evaluation are inclined to attribute their successes to ability and their failures to lack of effort or bad luck (Coopersmith, 1967; Hamachek, 1995; Marsh, 1984). They tend to be more 
open to positive feedback about their behaviour than to negative feedback that could degrade their performance or self-esteem (Mruk, 1995). Children with high self-esteem hold a conviction that they can successfully master challenges and overcome obstacles (Coopersmith, 1967; Rosenberg, 1979; Rutter, 1987).

Mruk (1995) describes self-esteem as an insulator against stress. The possible negative effects of threats on perceptions of self and the world, on the meanings given to what is happening, and on the actions the individual selects in response to a stressful situation are limited by how effective this shield or insulation is. Individuals who hold high self-esteem are better protected from fluctuations of worthiness and maintain a steadier position (Coopersmith, 1967; Mruk, 1995). Thus, self-esteem is able to act as a protective factor in the lives of resilient individuals.

In relation, Chemers, Watson and May (2000) found that people (in the study cadets) who have a higher self-esteem perform better after a leadership training compared to people with a lower self-esteem who also have followed the same training. Baumeister, Bushman and Campbell (2000) have investigated whether people who tend to use violence, have a low or high-self-esteem. The study found no direct relations between low self-esteem and an excessive amount of violence yet an interesting result showed that high self-esteem is a characteristic of both highly aggressive individuals and nonaggressive ones.

Rahim, Psenicka, Oh, Polychroniou, Dias and Rahman (2005) conducted a cross-cultural study on the relationship between emotional intelligence and transformational leadership. A total of 685 respondents from five countries were involved in this study. The study involved students' evaluation towards their supervisors' leadership. Results showed that empathy was positively correlated with transformational leadership. In addition, interpersonal skills have positive and significant relationship with leadership. The implication of the study is that supervisors need to use more of their competence which is empathy and interpersonal skill in increasing their transformational leadership. Similar findings were obtained by Cooper and Sawaf (1997), Goleman (1998) and Yukl (2006) when they found that a high sense of empathy is conceptually linked to effective leadership in organizational settings

Based on previous studies, the relationship between self-esteem and resilience are clear. There are also several studies on the association between self-esteem and leadership. However, what criteria of leadership can contribute towards resilience is still unexplored. The question also arises on whether these associations among the variables still hold true for both normal adolescents and illegal motorbike racers. This study therefore examines the differences of self-esteem, resilience and leadership among illegal motorbike racer and normal adolescents.

\section{Method}

\subsection{Respondents}

This research employed a survey method in which a set of standardized questionnaires were administered. The questionnaires were back-translated into Malay language and were administered during a three-month intervention program. A total of 140 respondents were involved in this study. The respondents consisted of 68 illegal motorbike racers while another 33 respondents comprised of normal adolescents. All of the respondents came from urban areas in Klang Valley, Malaysia. The age of respondents ranged from 16 to 22 years old.

\subsection{Instruments}

The questionnaires used were:

\section{i. $\quad$ Rosenberg Self-Esteem (RSE) Scale}

Self-esteem was assessed using the Rosenberg Self-esteem scale RSES (Rosenberg, 1965). The 10 items of the RSES assessed a person's overall evaluation of his/her worthiness as a human being (Rosenberg, 1979). Responses ranged on a 4-point scale from 1 (strongly disagree) to 4 (strongly agree). The RSES can be divided into an equal number of positively and negatively worded items measuring positive and negative self-esteem. The items were summed with the sum score ranging from 10 to 20. A higher score indicated higher self-esteem. Cronbach's alpha for the RSE was reported to be 0.73 . The reliability of RSE for the current study was 0.74 .

ii. The adapted Multifactor Leadership Questionnaire (MLQ)

The Multifactor Leadership Questionnaire (MLQ) which consists of 45 items was developed by Avolio and Bass (2004). It measures three dimensions of leadership namely transformational, transactional and laissez-faire leadership. For the purpose of the current study, only 16 items of transformational leadership was employed. The MLQ was reported to have good reliability with alpha ranging from 0.70 to 0.83 (Avolio \& Bass, 2004). The instrument has good validity of item total correlations and also has convergent validity with Myer-Briggs Type 
Indicator (MBTI) and 16 Personality Factors (16PF). The reliability of the adapted MLQ for the present study was 0.74 .

iii. Resilience Questionnaire (RQ)

The scale was developed by Organisational Health Psychologists. RQ was used widely by psychologists to identify level of resilience by analyzing eight dimensions which were self assurance, personal vision, flexible and adaptable, organized, problem solver, interpersonal competence, socially connected and active. The lowest possible overall RQ score was 32 while the maximum overall score was 160 . For individual RQ dimensions, the maximum possible score is 20; the lowest possible score is 4 . The scores can be interpreted according to the following levels of resilience: very resilient (141-160), resilient (116-140), somewhat resilient (61-115), and not very resilient (32-60). The reliability of RQ for the present study was 0.95 .

\section{Results and Discussion}

Results in Table 1 showed that self-esteem correlated significantly and positively with all the dimensions of resilience: self-assurance, $\mathrm{r}=0.57, \mathrm{p}<0.01$; personal vision, $\mathrm{r}=0.56, \mathrm{p}<0.01$; flexible, $\mathrm{r}=0.51, \mathrm{p}<0.01$; organized, $\mathrm{r}=0.53, \mathrm{p}<0.01$; problem solver, $\mathrm{r}=0.43, \mathrm{p}<0.01$; interpersonal competence, $\mathrm{r}=0.33, \mathrm{p}<0.01$; socially connected, $\mathrm{r}=0.47, \mathrm{p}<0.01$; and active, $\mathrm{r}=0.49, \mathrm{p}<0.01$. The findings showed that the higher the self-esteem, the higher resilience respondents have. (see Table 1).

Table 1. Correlation matrix between self-esteem, leadership and resilience dimensions among normal adolescents

\begin{tabular}{llllllllll}
\hline & 1 & 2 & 3 & 4 & 5 & 6 & 7 & 8 & 9 \\
\hline Self-esteem(1) & - & & & & & & & & \\
Leadership(2) & $0.45^{*}$ & - & & & & & & & \\
Self assurance(3) & $0.57^{*}$ & $0.63^{*}$ & - & & & & & & \\
Personal & $0.56^{*}$ & $0.49^{*}$ & $0.84^{*}$ & - & & & & & \\
vision(4) & & & & & & & & & \\
Flexible(5) & $0.51^{*}$ & $0.58^{*}$ & $0.83^{*}$ & $0.81^{*}$ & - & & & & \\
Organized(6) & $0.53^{*}$ & $0.57^{*}$ & $0.74^{*}$ & $0.68^{*}$ & $0.76^{*}$ & - & & & \\
Problem & $0.43^{*}$ & $0.61^{*}$ & $0.85^{*}$ & $0.69^{*}$ & $0.80^{*}$ & $0.76^{*}$ & - & & \\
solver(7) & & & & & & & & & \\
Interpersonal(8) & $0.33^{*}$ & $0.46^{*}$ & $0.76^{*}$ & $0.67^{*}$ & $0.72^{*}$ & $0.61^{*}$ & $0.69 *$ & - & \\
Socially & $0.47^{*}$ & $0.54^{*}$ & $0.76^{*}$ & $0.71^{*}$ & $0.76^{*}$ & $0.62^{*}$ & $0.68^{*}$ & $0.72^{*}$ & - \\
connected(9) & & & & & & & & & \\
Active(10) & $0.49^{*}$ & $0.54^{*}$ & $0.90^{*}$ & $0.82^{*}$ & $0.82^{*}$ & $0.76^{*}$ & $0.83^{*}$ & $0.78^{*}$ & $0.75^{*}$ \\
\hline
\end{tabular}

$* \mathrm{p}<0.01$

Similarly, results showed there were significant and positive correlations between leadership and all the dimensions of resilience: self-assurance, $r=0.63, p<0.01$; personal vision, $r=0.49, p<0.01$; flexible, $r=0.58$, $\mathrm{p}<0.01$; organized, $\mathrm{r}=0.57, \mathrm{p}<0.01$; problem solver, $\mathrm{r}=0.61, \mathrm{p}<0.01$; interpersonal competence, $\mathrm{r}=0.46, \mathrm{p}$ $<0.01$; socially connected, $\mathrm{r}=0.54, \mathrm{p}<0.01$; and active, $\mathrm{r}=0.54, \mathrm{p}<0.01$. This indicated that the higher the scores in leadership, the higher resilience respondents have.

The findings of positive and significant correlations between self-esteem and resilience were consistent with findings of previous studies (Barnard, 1994; Benard, 1991, 1995; Coopersmith, 1967; Hamachek, 1995; Marsh, 1984). Higher self-esteem indicated that adolescents have a positive evaluation of themselves and thus, this will instill in them the strength to face difficult challenges in life and overcome them successfully. This study also obtained significant correlations between leadership and resilience which meant that the higher skills of leadership that adolescents have, the higher their ability to be resilient and overcome life challenges. 
In contrast, results of Pearson correlation in Table 2 showed that there were no significant relationships between self-esteem and resilience dimensions among illegal motorbike racers. It was found that self-esteem did not correlate significantly with all the dimensions of resilience: self-assurance, $r=0.00, p>0.05$; personal vision, $r$ $=-0.14, \mathrm{p}>0.05$; flexible, $\mathrm{r}=0.16, \mathrm{p}>0.05$; problem solver, $\mathrm{r}=-0.21, \mathrm{p}>0.05$; interpersonal competence, $\mathrm{r}=$ $0.01, \mathrm{p}>0.05$; socially connected, $\mathrm{r}=0.05, \mathrm{p}>0.05$; and active, $\mathrm{r}=-0.04, \mathrm{p}>0.05$. Only the dimension of organized had significant relationship with self-esteem, $r=0.42, p<0.05$. This meant that self-esteem did not influence resilience. The high or low scores in self-esteem contributed little to resilience among illegal motorbike racers. (refer Table 2).

Table 2. Correlation matrix between self-esteem, leadership and resilience dimensions among illegal motorbike racers

\begin{tabular}{|c|c|c|c|c|c|c|c|c|c|}
\hline & 1 & 2 & 3 & 4 & 5 & 6 & 7 & 8 & 9 \\
\hline Self-esteem(1) & - & & & & & & & & \\
\hline Leadership(2) & -0.02 & - & & & & & & & \\
\hline Self assurance(3) & 0.00 & -0.01 & - & & & & & & \\
\hline $\begin{array}{l}\text { Personal } \\
\text { vision(4) }\end{array}$ & -0.14 & 0.08 & $0.47 * *$ & - & & & & & \\
\hline Flexible(5) & 0.16 & 0.18 & $0.35^{*}$ & $0.44^{*}$ & - & & & & \\
\hline Organized(6) & $0.42 *$ & 0.09 & 0.30 & 0.31 & $0.55 * *$ & - & & & \\
\hline $\begin{array}{l}\text { Problem } \\
\text { solver(7) }\end{array}$ & -0.21 & -0.09 & $0.52 * *$ & $0.76^{* *}$ & $0.42 *$ & 0.31 & - & & \\
\hline Interpersonal(8) & 0.01 & 0.01 & 0.17 & $0.47 * *$ & 0.33 & 0.15 & 0.31 & - & \\
\hline $\begin{array}{l}\text { Socially } \\
\text { connected(9) }\end{array}$ & 0.05 & 0.07 & 0.23 & $0.46^{* *}$ & $0.39 *$ & 0.20 & 0.30 & $0.56^{* *}$ & - \\
\hline Active(10) & -0.04 & 0.11 & 0.28 & $0.55 * *$ & $0.36^{*}$ & 0.05 & $0.56^{* *}$ & $0.50^{* *}$ & $0.49 * *$ \\
\hline
\end{tabular}

Similarly, results showed no significant correlations between leadership and all the dimensions of resilience: self-assurance, $r=-0.01, \mathrm{p}>0.05$; personal vision, $\mathrm{r}=0.08, \mathrm{p}>0.05$; flexible, $\mathrm{r}=0.18, \mathrm{p}>0.05$; organized, $\mathrm{r}=$ $0.09, \mathrm{p}>0.05$; problem solver, $\mathrm{r}=-0.09, \mathrm{p}>0.05$; interpersonal competence, $\mathrm{r}=0.01, \mathrm{p}>0.05$; socially connected, $r=0.07, p>0.05$; and active, $r=0.11, p>0.05$. The findings indicated leadership did not influence resilience and vice versa.

The findings of nonsignificant correlations between self-esteem and resilience among illegal motorbike racers who can be categorized as at-risk youths and delinquents were consistent with findings of previous studies (Oyserman \& Markus, 1990). Seligman (1995) demonstrated that it is not low self-esteem that causes low achievement at school, but the opposite: low achievement causes low self-esteem. Low self-esteem may reflect a realistic appraisal of negative experiences and low self-esteem will continue to exacerbate the young person's problems (McWhirter, McWhirter, McWhirter \& McWhirter (2004). This study also obtained nonsignificant correlations between leadership and resilience which meant that whatever leadership skills that illegal motorbike racers have, it was not used in increasing their ability to be resilient and overcome difficulties.

In order to strengthen the different results of correlation between self-esteem, leadership and resilience among normal adolescents and illegal motorbike racers, t-test analysis was used to test the significant differences of self-esteem, leadership and resilience based on normal adolescents and illegal motorbike racers. The results of t-test analysis in Table 3 showed that there were significant differences of self-esteem between normal adolescents and illegal motorbike racers, $\mathrm{t}=5.89, \mathrm{p}<0.05$. The mean was higher among normal adolescents of 22.04 compared to the mean of illegal motorbike racers 17.16. There was also significant difference of leadership between normal adolescents and illegal motorbike racers, $t=3.21, \mathrm{p}<0.05$. Normal adolescents showed a higher mean of 44.68 compared to illegal motorbike racers with mean of 39.18. However, there was no significant difference of resilience between normal adolescents and illegal motorbike racers, $t=1.19, \mathrm{p}>0.05$. These findings were also consistent with past studies. For instance, Oyserman and Markus (1990) reported that delinquents have lower self-esteem than nondelinquents. Hermann, McWhirter and Sipsas-Hermann (1997) 
found that young adolescents with lower self-concepts were significantly more involved in street gang activity than peers who possessed higher self-concepts. (refer Table 3).

Table 3. Differences of self-esteem, leadership and resilience based on normal adolescents and illegal motorbike racers

\begin{tabular}{llccccc}
\hline & & $\mathrm{N}$ & Mean & SD & df & $\mathrm{t}$ \\
\hline Self esteem & & & & & & \\
& Normal & 68 & 22.04 & 3.68 & 99 & $5.89^{*}$ \\
& Illegal racers & 33 & 17.76 & 2.84 & & \\
Leadership & & & & & & \\
& Normal & 68 & 44.68 & 8.37 & 99 & $3.21^{*}$ \\
& Illegal racers & 33 & 39.18 & 7.42 & & \\
Resilience & & & & & & \\
& Normal & 68 & 116.75 & 18.98 & 96.60 & 1.19 \\
& Illegal racers & 33 & 113.21 & 10.73 & & \\
\hline
\end{tabular}

$* \mathrm{p}<0.05$

\section{Conclusion}

Several conclusions can be drawn from this study. First, normal adolescents have higher self-esteem, leadership and resilience and these profiles can be the protective factors that enabled them to experience life positively and successfully. In contrast, illegal motorbike racers have lower self-esteem, leadership and resilience skills and these criteria became risk factors which may hinder them to become successful individuals. Thus, these need to be addressed in order to help adolescents realize their full potential.

Second, understanding the roles of self-esteem and leadership in contributing towards resilience may be a key factor in identifying variables related in increasing resilience among youths at risk. Implication of this study emphasizes the need for continuous intervention programs in order to empower these at risk youth. Future research should explore the role of other variables that may include not only personal characteristics, but also family and school variables that can influence resilience among at risk youth.

\section{References}

Avolio, B. J., \& Bass, B. M. (2004). Multifactor Leadership Questionnaire: Manual and Sampler Set (3 ${ }^{\text {rd }}$ ed.). California: Mind Garden.

Barnard, C. P. (1994). Resiliency: A Shift in our Perception. American Journal of Family Therapy, 22(2), 135-144. http://dx.doi.org/10.1080/01926189408251307

Baumeister, R. F., Bushman, B. J., \& Campbell, W. K. (2000). Self-esteem, Narcissism and Aggression: Does Violence Result from Low Self-esteem or from Threatened Egoism? Current Directions in Psychological Science, 9(1), 26-29. http://dx.doi.org/10.1111/1467-8721.00053

Benard, B. (1991). Fostering Resiliency in Kids: Protective Factors in the Family, School, and Community (Contract No. S188A00001). Portland, OR: Western Regional Center for Drug-Free Schools and Communities. (ERIC Document Reproduction Service No. ED 335 781).

Benard, B. (1995). Fostering Resilience in Children. ERIC Digest. Retrieved 8 December 2010, from http://www.ed.gov/databases/ 1 -igests/ed386327.html

Buhrmester, D., Furman, W., Wittenberg, M. T., \& Reis, H. T. (1988). Five Domains of Interpersonal Competence in Peer Relationships. Journal of Personality and Social Psychology, 55(6), 991-1008. http://dx.doi.org/10.1037/0022-3514.55.6.991

Bushweller, K. (1995). The Resilient Child. American School Board Journal, 182(5), 18-23.

Chemers, M. M., Watson, C. B., \& May, S. T. (2000). Dispositional Affect and Leadership Effectiveness: A Comparison of Self-esteem, Optimism, and Efficacy. Personality and Social Psychology Bulletin, 26(3), 267-277. http://dx.doi.org/10.1177/0146167200265001

Clark, P. (1995). Risk and Resiliency in Adolescence: The Current Status of Research on Gender Differences. Equity Issues, 1(1), 1-13. 
Cooper, R. K., \& Sawaf, A. (1997). Executive EQ: Emotional Intelligence in Leadership and Organizations. New York: Grosset/Putman.

Coopersmith, S. (1967). The Antecedents of Self-esteem. San Francisco: W. H. Freeman.

Garmezy, N. (1991). Resiliency and Vulnerability to Adverse Developmental Outcomes Associated with Poverty. American Behavioral Scientist, 34(4), 416-430. http://dx.doi.org/10.1177/0002764291034004003

Garmezy, N., \& Rutter, M. (Eds.). (1983). Stress, Coping, and Development in Children. New York: McGraw-Hill.

Goleman, D. (1998). Working with Emotional Intelligence. New York: Bantam Books.

Gore, S., \& Eckenrode, J. (1994). Content and Process in Research on Risk and Resilience. In R. J. Haggerty, L. R. Shexrod, N. Garmezy, \& H. Rutter (Eds.), Stress, Risk, and Resilience in Children and Adolescents. Process. Mechanisms, and Interventions (pp. 19-63). Cambridge, England: Cambridge University Press.

Green, A. E., Gesten, E. L., Greenwald, M. A., \& Salcedo, O. (2008). Predicting Delinquency in Adolescence and Young Adulthood: A Longitudinal Analysis of Early Risk Factors. Youth Violence and Juvenile Justice, 6(4), 323-342. http://dx.doi.org/10.1177/1541204008320261

Hamachek, D. (1995). Self-concept and School Achievement: Interaction Dynamics and a Tool for Assessing the Self-concept Component. Journal of Counseling and Development, 73(4), 419-425. http://dx.doi.org/10.1002/j.1556-6676.1995.tb01775.x

Hauser, S. T., Vieyra, M. A. B., Jacobson, A. M., \& Wertlieb, D. (1985). Vulnerability and Resilience in Adolescence: Views from the Family. Journal of Early Adolescence, 5(1), 81-100. http://dx.doi.org/10.1177/0272431685051008

Hermann, D. S., McWhirter, J. J., \& Sipsas-Hermann, A. (1997). The Relationship between Dimensional Self-concept and Juvenile Gang Involvement: A Focused Examination. Unpublished manuscript: Arizona State University.

Hollander, E. P. (1992). Leadership, Followership, Self and Others. Leadership Quarterly, 3(1), 43-54. http://dx.doi.org/10.1016/1048-9843(92)90005-Z

Hutchinson, R. L., Tess, D. E., Gleckman, D., \& Spence, W. C. (1992). Psychosocial Characteristics of Institutionalized Adolescents: Resilient or At Risk? Adolescence, 27(106), 339-356.

Jackson, C., \& Wilson, G. D. (1993). Mad, Bad or Sad? The Personality of Bikers. Personality and Individual Differences, 14(1), 241-242. http://dx.doi.org/10.1016/0191-8869(93)90194-8

Jago, A. G. (1982). Leadership: Perspectives in Theory and Research. Management Science, 28(3), 312-336. http://dx.doi.org/10.1287/mnsc.28.3.315

Kaplan, H. B. (1999). Towards an Understanding of Resilience: A Critical Review of Definitions and Models. In Glantz, M.D. \& Johnson, J. (Eds), Resilience and Development: Positive Life Adaptations. New York: Plenum Press.

Klarreich, S. H. (1998). Resiliency: The Skills Needed to Move Forward in a Changing Environment. In S.H. Klarreich (Ed.), Handbook of Organizational Health Psychology: Programs to Make the Workplace Healthier (pp. 219-238). Madison, CT: Psychosocial Press.

Kurth-Schai, R. (1988). The Roles of Youth in Society: A Reconceptualization. Educational Forum, 52(2), 113-132. http://dx.doi.org/10.1080/00131728809335473

Linquanti, R. (1992). Using Community-wide Collaboration to Foster Resiliency in Kids: A Conceptual Framework (Contract No. S188A00001). Portland, OR: Western Regional Center for Drug-Free Schools and Communities. (ERIC Document Reproduction Service No. ED 353 666).

Malbi, R. S., \& Reasoner, R. W. (2000). Self-Esteem, Enhancing. Kuala Lumpur: Self-Esteem Seminars Sdn. Bhd..

Marsh, H. W. (1984). Relations among Dimensions of Self-attribution, Dimensions of Self-concept, and Academic Achievements. Journal of Educational Psychology, 6(6), 1291-1308. http://dx.doi.org/10.1037/0022-0663.76.6.1291

Masten, A. S. (2001). Ordinary Magic: Resilience Processes in Development. American Psychologist, 56(3), 227-238. http://dx.doi.org/10.1037/0003-066X.56.3.227 
Masten, A. S., Best, K. M., \& Garmezy, N. (1990). Resilience and Development: Contributions frorn the Study of Children Who Overcome Adversity. Development and Psychopathology, 2(4), 425-444. http://dx.doi.org/10.1017/S0954579400005812

McMillan, J. H., \& Reed, D. F. (1994). At-risk Students and Resiliency: Factors Contributing to Academic Success. Clearing House, 67(3), 137-140. http://dx.doi.org/10.1080/00098655.1994.9956043

McWhirter, J. J., McWhirter, B. T., McWhirter, E. H., \& McWhirter, R. J. (2004). At Risk Youth: A Comprehensive Response ( ${ }^{\text {rd }}$ ed.). Belmont, CA: Brooks/Cole-Thomson Learning.

Mruk, C. (1995). Self-esteem. Research, Theory, and Practice. New York: Springer.

Murphy, L. B. (1987). Further Reflections on Resilience. In E. J. Anthony \& B. J. Cohler (Eds.), The Invulnerable Child (pp. 84-105). New York: Guilford Press.

Newcomb, M. D. (1992). Understanding the Multi-dimensional Nature of Drug Use and Abuse: The Role of Consumption, Risk Factors, and Protective Factors. In M. Glantz \& R. Pickens (Eds.), Vulnerability to Drug Use (pp. 255-298). Washington, DC: American Psychological Association. http://dx.doi.org/10.1037/10107-010

Northouse, P. G. (2009). Leadership: Theory and Practice ( $5^{\text {th }}$ ed.). USA: Sage publication Inc.

Oyserman, D., \& Markus, H. R. (1990). Possible Selves and Delinquency. Journal of Personality and Social Psychology, 59(1), 112-125. http://dx.doi.org/10.1037/0022-3514.59.1.112

Rhoads, D. J. (1994). Resiliency Research: An Exploration of Successful Coping Patterns. Eta Sima Gamma Monograph Series, 12(1), 50-58.

Rahim, M. A., Psenicka, C., Oh, S. Y., Polychroniou, P., Dias, J. F., \& Rahman, M. S. (2005). Relationship between Emotional Intelligence and Transformational Leadership: A Cross-cultural Study. Retrieved 17 November, 2009, from http://icam1990.com/Conference? LinkClick.aspx?Fileticket=iYH-YR0AUdM\%3D\&tabid=171\&mid=659

Rosenberg, M. (1965). Society and Adolescent Self-image. Princeton NJ: Princeton University Press.

Rosenberg, M. (1979). Conceiving the Self. New York: Basic Books.

Rutter, M. (1979). Protective Factors in Children's Responses to Stress and Disadvantage. In M. W. Kent \& J. E. Rolf (Eds.), Primary Prevention of Psychopathology: Vol. 3. Social Competence in Children (pp. 49-74). Hanover, NH: University Press of New England.

Rutter, M. (1987). Psychosocial Resilience and Protective Mechanisms. American Journal of Psvchiatry, 57(3), 316-331.

Salami, S. O. (2010). Moderating Effects of Resilience, Self-esteem and Social Support on Adolescents' Reactions to Violence. Asian Social Science, 6(12), 101-110.

Seligman, M. E. P. (1995). The Optimistic Child: A Revolutionary Program that Safeguards Children against Depression and Builds Lifelong Resilience. New York: Houghton Mills.

Stuart, C. (1994). Resilient Adolescents and Peer Counseling: Issues and Opportunities. Journal of Emotional and Behavioural Problems, 3(2), 48-49.

Tarwater, P. (1993). Glass, Plastic, or Steel? Childhood Education, 69(5), 272-273.

Walker, L. S., \& Greene, J. W. (1987). Negative Life Events, Psycho-social Resources, and Psycho-physiological Symptoms in Adolescents. Journal of Clinical Child Psychology, 16(1), 29-36. http://dx.doi.org/10.1207/s15374424jccp1601_4

Werner, E. E., \& Smith, R. S. (1982). Vulnerable but Invisible: A Longitudinal Study of Resilient Children and Youth. New York: McGraw-Hill.

Werner, E. E., \& Smith, R. S. (1992). Overcoming the Odds: High Risk Children from Birth to Adulthood. London: Cornell University Press.

Yukl, G. (2006). Leadership in Organizations. New Jersey: Pearson Prentice Halll.

Zaid Ahmad, Nobaya Ahmad, \& Haslinda Abdullah. (2009). Urbanism, Space and Human Psychology: Value Change and Urbanization in Malaysia. European Journal of Social Sciences, 11(3), 464-470. 